\title{
Study and Performance of Sepah Bank in International Affairs and Its Impact on the Economy of Iran
}

\author{
Gh. Mirshekari ${ }^{1} \&$ H.Taleghani ${ }^{2}$ \\ ${ }^{1}$ Department of Law, Bushehr branch, Islamic Azad University, Bushehr, Iran \\ ${ }^{2}$ University of Glasgow, Glasgow, Scotland \\ Correspondence: Gh. Mirshekari, Department of Law, Bushehr branch, Islamic Azad University, Bushehr, Iran. \\ E-mail: ghmir54@yahoo.com
}

\author{
Received: February 14, 2016 Accepted: March 8, 2016 Online Published: March 31, 2016 \\ doi:10.5539/jpl.v9n2p192 URL: http://dx.doi.org/10.5539/jpl.v9n2p192
}

\begin{abstract}
Banking system was born with the establishment of Sepah Bank in 1304. This bank has special role in international trade, financial and economic and monetary relations. Sepah bank by allocating the credit and providing the necessary resources for foreign investment and international trade after the Islamic Revolution in Iran and alignment with government policies has always had a special place in macroeconomic. In 1386 this Bank was sanctioned by America government, and since then it has been consistent with this conditions and when was sanctioned by United Nations as first Iranian bank because of Iran's nuclear program, how to comfort with this status and to fight was placed on the agenda. By establishing a special committee in bank based on the leader directions to resist economy, alternative ways to get out of the existing situation was carried out and Sepah bank was considered as a pattern for next sanctioned bank.
\end{abstract}

Keywords: foreign investment, international affairs, resistance economy, international sanctions, macroeconomics

\section{Introduction}

Each organization needs to have performance evaluation system to determine the extent of the appropriateness and quality of its activities, especially in complex and dynamic environments. Lack of performance evaluation system in an organization means the lack of communication with inside and outside of the organization that leads to aging and consequently organization death. Also, banks such as other organizations in Iran to provide more diverse services, faster and more modern and to continue to survive in extensive wave of information and to develop banking special services, needs to evaluate continues performance of their branches. Based on documentary evidence the existing methods to evaluate branches performance of banks has often been experimental and lack of strong scientific support and because lack of standardization of these methods, its results are not comparable with each other in different banks.

Banking in Iran during recent decade has been faced with changes in deregulation field and new technologies in services and determining the growth objectives from banks side which are often governmental leading this system to being competitive. With increasing competition field in the banking system of Iran, the bank must constantly monitor their performance and measure their performance each year using appropriate models compared to others. In this context, banks according to their competitive advantages and strengthening them can ensure their success in competing with rivals at high levels.

\section{Sepah Bank in International Trade Field}

Entry to all areas of international trade and providing international trade financing is the main missions of Sepah bank. Entering to the field of investment and international trade requiring providing necessary resources that because of slowing of the economic growth process, more intense competitive challenges and unjust sanctions from the international community, this factor has been facing a lot of difficulties.

\subsection{The Performance of Sepah Bank in International Oil Projects}

Due to the economy's bank-orienting in Iran and providing finance about $90 \%$ of civil projects and international investment by the banking system, state-owned banks including Sepah Bank given its old finds a special role in 
this context [1].

In terms of sanctions from 1393 and with a focus on heavy slogan "Jihad management" the oil projects were decided in the banking system and basic infrastructure of investment was provided in this area and it leads to improve the performance of Sepah Bank in order to achieve resistance economy.

Sepah bank in the context of providing finance and investment in the fields of international oil projects in 1393 by using various resources including technical and financial manpower contributed to achieving the goals of resistance economy and by preparing the infrastructures and strategic plan in 1394, leaded to a big jump in the country's economy and linked the concept of resistance economy to Jihad management. Sepah Bank increased the given facilities in the field of oil and industrial projects in 1393 compared with previous years by 100 milliard rials. Sepah bank performance in the field of currency.

Sepah Bank's foreign exchange activities in 1394 compared to the same period in last year has reached to $\$ 3$ milliard and 500 million, which the growth in foreign exchange activities of Sepah Bank has also had a favorable impact on the performance of the other banks [2].

Sepah Bank's foreign exchange activities in the investment portfolio, including letters of credit, guarantees, is converting to securities and derivatives, which resulted in an increase in wage revenues and other disadvantage revenues.

Offering a variety of new services, electronic banking, financial advisory services, private banking and the use of financial derivative instruments in international banking are a part of the new and profitable services of Sepah Bank.

The most important types of guarantees issued by the Bank Sepah include:

Company guarantee in tender or auction, guarantees of good performance of obligations arising from contracts, payment guarantees, margin payment refund guarantee, Customs warranty

The most important openable credit in Sepah Bank include:

Deferred credit (usance), visual letters of credit, import or export letters of credit, irreversible letters of credit, irrevocable letter of credit, letter of credit confirmed, unconfirmed letters of credit, letters of credit back to back, transferable letter of credit, credit of non-transferable documents, red clause letter of credit, revolving letter of credit.

\section{Sepah Bank Sanction and Standing with It}

Today it is said large plans and firms to provide finance should move to the capital market, but the market also is affected the banking system and banks support this market.

In the absence of a strong currency unit, Iran will finds difficult continuing to its current behavior. Thus, the United Nations, Europe and America union have taken steps to isolate Iranian banks. At the beginning of 2006, United Nations ordered to member states not to interact with Sepah Bank and other firms related to that under any circumstances. As well as imposed some restrictions on transactions with two other banks, namely Saderat bank and Melat bank. In its last action, national unions subjected "the first eastern Saderat bank" is placed in Malaysia to these restrictions. Last month, Australia, Canada and Europe union also presented a list of Iranian banks for sanctions. America, for its part, in addition to those banks that were selected at the United Nations, sanctioned 16 other Iranian banks [3].

\subsection{Sanctions by America against Sepah Bank}

\subsubsection{Banking Sanctions}

The first Iranian banks which was sanctioned was Sepah Bank. Namely the beginning of banking sanctions was started from Sepah Bank and reached to other banks and finally to the central bank. Sepah Bank in Dey 191385 (9 January 2007) was sanctioned by the United States department of the Treasury.

America Treasury Department said in a statement on the reasons for the boycott's Sepah Bank. In this statement Sepah Bank's sanction which had been enacted by executive order 13382 in Tir 1384 was documented. In this executive order some institutions active in Iran's missile part are sanctioned by America, and it is indicating that institutions which provide services to sanctioned entities will be sanctioned or punished.

The statement said, "Today Sepah Bank due to support and providing services to sanctioned companies will be sanctioned" and accounts the reasons for sanctions as following:

Financing and delivery of services to Iranian Aerospace Industries (AIO) 


\section{Martyr Hemmat Industrial Group}

\section{Martyr Baqeri Industries Group}

These institutions have already been sanctioned by America as developers and dissemination of weapons of mass destruction (WMD) in July 1386.

In this statement the reasons for Sepah Bank's sanction will be discussed in detail, which all of them are in the area of weapons of mass destruction (or weapons with a high destruction). As a result, the sanctions for Sepah bank from America is not related to Iran's nuclear activities [4].

\subsubsection{United Nations Security Council Sanctions}

Sepah Bank has also been sanctioned by the UN. Four months after being sanctioned Sepah Bank by America, the bank was also sanctioned by the UN Security Council. In Resolution 1747, which was issued in 4 Persian date Farvardin 1386, Sepah Bank according to the same reasons stated by America, was banned. Namely the financial support and providing services to the aerospace industries of Iran, martyr Hemmat Industrial Group and martyr Bakeri Industries Group (these institutions has been sanctioned in UN's pervious resolutions). Sepah Bank sanctions by the Security Council is not relevant to Iran's nuclear issue. After leaving the Iranian nuclear file from Board of Governors to the Security Council, Iran sanctions was done in the various times and in the short period from each other, but in the meantime, Iran have had good money exchanges through its banking system with countries in the world so that most of generated sanctions has been neutralize and this made western officials and America convinced to sanction the Iran's banking system in order to deactivate financial power in international arena.

\subsubsection{Europe Union Sanctions}

Europe Union in less than a month that was passed from the UN Security Council resolution, imposed sanctions on Sepah Bank. In 441/2007 which is the amendment Act 423/2007, the sanctions were imposed. As a result of the same reasons stated in the resolution has also been documented.

Table 1. Europe Union sanctions

\begin{tabular}{cllllr}
\hline Sanction title & \multicolumn{2}{c}{ America } & \multicolumn{1}{c}{ Europe } & United nations & \multicolumn{2}{c}{ Conclusion } \\
\hline Sepah Bank & Excutive order & Approval 2007/441 & Resolution 1747 & Sepah & bank \\
& 13382, supporting & The same reasons & The same reason & sanction is not \\
& related to the \\
& and providing & & & nuclear issue \\
& services to & & \\
& Iran Aerospace & & \\
& Industry & & \\
& Martyr Hemmat & & \\
& Industrial Group & & \\
& Martyr Baqeri & & \\
& Industrial Group & & \\
\hline
\end{tabular}

\subsection{Comparison between Sepah Bank with Sanctions}

Banking industry was one of the first sectors of country that suffered widespread boycott. The sanction imposed on major and well known banks of Iran especially Sepah Bank and the head of that the central bank has made high pressure on the banking network in recent years. The sanctions led to the highly cost transferring including oil and sometimes with several months lag.

Sepah Bank owed much of their income received from the world banking wages and by sanctioning the financial structure of Sepah Bank was strongly faltered. Now if the resources blocked by state banks which have widespread foreign branches in all over the world releases, the good profitability and capital a will be given to these banks. However, there is also several other private banks on the list of sanctions [5].

The amount obtaining from country exports is a function of the amount of that when the trade facilitated, as a result, non-oil exports also will be flourished. 
Perhaps one of the main concerns in recent years, the banking system was faced with has been the issue of sanctions, which Western countries imposed in an unfair actions against country banks. The sanctions include several banks, however with the progress of negotiations, has been canceled in the case of some banks and it is expected by reaching to a final agreement on the nuclear negotiations, the sanctions canceled for all banks [6].

The banking system, provides a set of services to its customers that one of the most important of such services is in the areas of cross-border and overseas. For example, when a businessman plans to foreign trade and intends to import or export some commodities, is required set of banking actions such as LC openness.

Banking sanctions have made banks unable to offer this services to our merchants and our traders force to relay on neighboring countries such as the United Arab Emirates, to open LC, that consequently such methods increase their commercial operations cost and finally this cost prorated on imported goods. In the meantime, banks themselves due to being deprived of such operations have lost part of their income [7].

Imposing such sanctions is effective on the inter-bank operations of our country with other countries in the world and banks can expand the scope of their activities in other countries.

The first impact that the sanctions cancelation have on the country's banking system is that trades through the banking system returns to pre-sanctions status which this issue ultimately will affect the cost of imported goods. Also the trader who is going to export items in which Iran has relative advantage, such as pistachios, carpets, saffron, etc. can sell their goods at lower cost to the customers in the word markets by reducing banking costs and opening the LC through national banks inside or outside the destination countries. From the other hand, since first day banks sanction which was started with Sepah Bank, the opening credits in foreign currency reserves account was in trouble and compatriots who communicate with our banks in abroad their activities was faced with trouble that with the elimination of sanctions, is expected these problems go away. Global confidence in the banks that suffered during these years will be revived and our banks can find their rightful place in the world.

Bank operates as a network of vessels and capillaries in the body of country economy that provides and distributes the required assets and liquidities to different parts of the body. The western countries with the aim of getting hit to the country economy has faced banks with sanctions, although these sanctions have had damages with itself in some parts, but banks, nevertheless, couldn't manage to keep their acceptable level of quality service. Therefore, removal of sanctions is the concept of simplifying bank process serving as arteries and capillaries of the economy body, resulting in all parts of the economy that will benefit from this area that were in trouble [8].

\subsubsection{Proposing Sanctions Removal of Sepah Bank to Negotiators}

Sepah Bank was sanctioned by America before Mely Bank in 85 years, as a result, all of the foreign exchange activities that have with America financial system was cut and the result of sanction belong to the years 86 and 87 is still remained. At the last days of year 85 the static that represents the currency and financial activity of Sepah Bank was offered. Total currency transactions of the bank was about 19 milliard and 984 million dollar in 1385 that Strongly fell in 1385 years, and reached to 3 milliard and 925 million dollar. In 1387 the total transactions done has been estimated around 4 milliard and 157 million dollar that in compared to transaction year, was reduced to about 15 milliard and 827 million dollars [9].

Examining the current and financial activities of Sepah Bank shows that the largest decrease in the headlines as "other transactions" occurred at a rate of $95 \%$. The volume of activity of Sepah Bank in this sector during 1385 has been about 9 milliard and 409 million dollars which in 1387, it reached to 426 million dollars.

After the headline, the volume of credits of the bank with $60 \%$ decrease nearly 2 milliard and 861 million dollars in 1385 has reached to one milliard and 138 million dollars in 1387.

High cost of money has made difficult the equipment of resources for banks in 1385 . In 385 , from a total of $\$ 30$ milliard foreign exchange, 5.7 milliard dollar has been through Sepah Bank, since 1386 with the incidence of sanctions Sepah Bank current operation was stopped.

A plans to remove sanctions has been designed by Sepah Bank which for its implementation negotiating have been negotiating with senior State Department officials. Sepah Bank by making connection with Keshavarzi and Maskan Banks while retaining old customers was entrusted until needs of customers provided.

According to this plan $\$ 1.5$ milliard from the National Development Fund in the areas of upstream oil industries, investment was done in 5 oil fields. In the upstream oil industries, 1/8 million dollars, $1 / 2$ million dollars in the petrochemical field and $\$ 150$ million was invested in the power sector. Producing $60 \%$ of iron ore has been 
invested by Sepah Bank, and in the power supply, establishing power plants and sealants have been conducted with the participation of the Bank. In 1391 and the beginning of 1392, 2,800 milliard toman of bonds was sold by Sepah Bank which the most of that has been paid to product designs. In 9 months of 1393, six thousand dollars has been disbursed by Sepah Bank that have had $75 \%$ facilities for the agricultural sector compared to the year before payment [10].

2300 milliard toman facilities has been paid as rial from the National Development Fund to the agricultural sector as well as 3 milliard toman in industry sector and 2,200 milliard toman in the business sector and 700 milliard toman to renew texture worn. The banking system due to its sensitivity is strongly vulnerab, so if there is low weakness in the banking system its traces will be revealed.

In the sanctions discussion the main purpose during the negotiations was removing some trade barriers, such as Swift, sales, shipping and insurance, but the difficulty is to adjust the agreement in a way that could pave the way for long-term and medium-term investment between Iran and other countries, especially Europe [11].

\subsubsection{Sepah Bank Situation Aftermath of the Sanction}

West have boycotted the country's largest banks, banks such as Melli, Saderat, Mellat so that the foreign exchange of banks has been reduced, in contrast, Iran by some private and academic banks is sought to revive the opportunities missed.

Banking system performance report in last year's shows that the weight balance of foreign exchange has getting heavier in advantage of private non-sanction so that the composition of its foreign exchange from 1386 (when the sanctions imposed on the large bank) to the next, trend to raise But in contrast, the National Bank foreign exchange activities of Melly, Saderat, Sepah, and Mellat bank has been faced with west sanction and has taken a reduced form. Turning to the payment order was another alternative for Iran to scape pressures imposed. Payment order is against letter of credit and means doing transactions in cash.

Following the conclusion of the nuclear negotiations, a deal done, and canceling the financial, banking and economical sanctions the experts, managers and managers predict that the level of trade between Iran and the countries of Europe, Asia and US will be gradually increased and as a result companies, banks and institutions that have the capacity for branches and offices abroad, will be able to increase the amount of income, profits and their transactions by using their potential, while helping the business environment and boost the trade transactions between Iran and increasing country's economy growth [10].

Since the trade and transport of money and payment order and bank guarantees and ... can get expected achievements in short and within a few months and obtain profit faster than the industry and long-term investments. As result, for Tehran Exchange shareholders, commercial banks with foreign branches attracts more attention than the other institutions and will be considered more in terms of profitability and stock future and price and earnings per share [11].

In other words, at the present due to capacity available for banks, especially Melly banks, Sepah Bank, Mellat and Tejarat banks than other institutions are more subject to assessment of shareholders and investors, and stakeholders and Stock actives account a good future for such institutions. Experts predict that with the lifting of the sanctions, more than 50 branches of commercial banks can have greater activity and have more revenue abroad.

According to the US Treasury's Office of Foreign Assets Supervision, Iranian banks that have branches abroad, including banks, Saderat, Mellat, Melly, Tejarat, Sepah, Keshavarzi, Maskan, Sanaat and Madan and Iran Foreign Investment Company. However, Iranian banks in the cities of Los Angeles and New York, work as agency [10 11].

Foreign branches of Sepah Bank is placed in Frankfurt Germany, London England, New York US, Paris France, and Rome and Milan Italy that after the lifting of the sanctions by following the activities will make the economy more profitable for Iran.

Based on the conclusion of nuclear talks in Vienna which was informed on 23 June 1394 to December will probably reach to the final conclusion and signing the agreement, lifting the economic and financial sanctions has been one of the priorities of the Islamic Republic of Iran to stop all actions done by countries in running Security Council resolutions.

All Security Council resolutions $(1696,1737,1747,1803,1835,1929$ and 2224) in the first and in the form of Article 41 of the Charter of the United Nations that 6 previous resolutions has been issued in the same form and placed Iran under Article 41 of Chapter 7 of the Charter, all economic and financial sanctions imposed will be 
finished [12].

All property and funds belonging to the government, central bank and other real or legal person which are blocked by foreign financial institutions, will be released from the date to run Brjam and without any pre-conditions can be used by owners of the property and funds. The Government of the Islamic Republic of Iran, the Central Bank and other banks, including Sepah Bank can do the following activities $[12,13]$

1. Publishing and selling bonds

2. Publicating and salling the bonds issued by government guarantee

3. Receiving foreign loans from international institutions such as the World Bank and other private banks

4. Purchase of dollar transactions through non-US banks

5. Receiving export guarantees from the relevant institutions, banks and financial institutions of Iran can attempt to trading and commercial activities with foreign banks and financial institutions as following.

6. Creating agency relations

7. The use of messaging services including swift

8- Establishment of agencies, branches or subsidiaries

9. The opening of letters of credit, documentary bill and issuing of bank guarantees

10. Investments in shares of financial institutions and foreign banks and making partnerships with them.

11. The sale of shares loan to foreign banks and financial institutions according to national law

12. Currency transfers inside and outside the country or to the bank account itself [13].

13. Buying and selling the international bonds or other international securities in your account or the bank customers' account

\section{Receiving foreign loans and credit facilities}

15. Performing other financial operations and banking and banking related activities with each of the above as well as trade in gold and precious metals.

The Central Bank of the Islamic Republic of Iran, IRISL, NIOC, NITC and subsidiaries, Iran air and many other institutions, banks and institutions of the country (a total of about 800 natural or legal person) get outside the scope of sanctions and these actions will widely change the business environment and the country's business and to the extent that this release will occur from the sanctions will be effective on banks and branches of foreign commercial banks and will increase their profitability and income [13].

With greater access to the areas of trade, technology, finance and energy, and facilitating commercial and banking transactions and eliminating restricting economic cooperation with Iran in all areas, including investment in oil and gas, petrochemical industry and other fields will increases the growth financing transport, contracts Remittances and guarantees and foreign exchange, and in all these fields, the Iranian banks located outside the country will play an important role $[14,15]$.

\section{Conclusion}

Sepah Bank in economic crisis and sanctions conditions granted to facilities and allocating resources, particularly to oil and gas upstream industry which is in unjust sanctions by west has presented a glittering career. America Treasury Department for the banks that are in the proliferation of weapons of mass destruction stablishes some limits including Sepah Bank sanctions. As a result, when facing with sanction it can't be located in front of dollar and euro transactions in accordance with the sanctions and assets in the countries operating sanction has been blocked and interact with that bank is offensive. However, Sepah Bank has faced obstacles in the allocation of resources, including:

- Mismatch between interest rates of profits and inflation

- Sanctions and lack of access to external sources

- Legal deposit banks with the Central Bank

- The lack of new financing tools

- Legal deposit of banks by the Central Bank

- The lack of new supplying financing tools 


\section{Proposals}

In order to enhance the role of Sepah Bank in the economy area after the period of sanctions, the following is recommended:

- The capital increase of the bank to improve its credit;

- Approval of laws and regulations required by the relevant institutions and organizations such as government, parliament, the securities and central bank to issue Islamic securities;

- A review of the current guidelines issuing the securities, as well as studies about type of Islamic securities and experience of other countries;

- To lay the groundwork to more colorful presence of companies to raise capital in order to develop and expand the dissemination of Islamic securities;

- Revision in the interest-free banking, monetary law as well as rules, regulations and guidelines applicable to the provision of the financial system;

- Taking appropriate preparation and revision of laws to facilitate the process of receiving Non-Current Bank's Demands;

- Strengthen the insurance industry to secure the economic activity;

- Use of the capacities of the National Development Fund;

- Increasing the attractiveness of issued securities, including current bonds in order to encourage investors to buy them;

Negotiations with the Islamic Development Bank and similar institutions for supplying finance and applying their best practices in this regard.

\section{References}

Ajili, H., \& Keshavarz, M. E. (1392 Winter). the impact of international sanctions on Iran's economic development. development strategy magazine, 36-58.

Citations courtesy of Director of National Iranian Oil Company to Sepah Bank, March 1393.

Export Development Magazine, "a cleverly design to deal with banking sanctions", December 1389, p 88, p 12.

Kamijani, A. (1383). the central bank and the banking system. Journal of Accounting, (159), 6.

Khoshroo, S. (1393). how the economic sanctions against Iran by America. Journal of Energy Economics, (49), 23.

Magazine of Economic news. banking history in Iran. June 1382, p 99, p 15.

Masoudi, A. R. (1386). Banking Law. published by Taban Kharad, Tehran. p. 22

Pashaei Pham, R. (n. d.). Examining the economically optimal size of banks (Case Study of Sepah Bank).

Roodposhti Shafi'i, M., \& Imami, S. M. (1392, Fall). Sanctions Pathology of banking system. Journal of Financial Engineering and Management of Securities, 16-52.

Sedghi, V., \& Cheraghi, M. (1391, Fall). sanctions against Iran and elegance against Iran by United States. Journal of Regional Studies, (46), 177.

Shahriar, H. P. (1390). history and evolution of banks and banking in Iran. Journal of Payame bank, (510), 31.

Taghavi Nejad, K. (1394). a coherent, responsive and engaged with Bank Sepah beginning of new era in the banking system. Journal of Economics and Insurance, (56), 6.

Vaez Barzani, M., \& Shah Mohammadi, F. (1392). the effect of regulatory reform on the cost structure and competitiveness in the branches of Sepah Bank. the first national conference on monetary and banking Management Development, p. 131.

Vhidnia, G. (1386). banking sanctions. Journal of Banking and Economics, (81), 41.

Yavari, K., \& Mohseni, R. (1392). the effects of trade and financial sanctions on Iran economy. the magazine of strategy and Parliament, (61), 9. 


\section{Copyrights}

Copyright for this article is retained by the author(s), with first publication rights granted to the journal.

This is an open-access article distributed under the terms and conditions of the Creative Commons Attribution license (http://creativecommons.org/licenses/by/3.0/). 